\title{
Epidemiologic and Clinical Characteristics of Patients with Covid-19 in Central Java, Indonesia
}

\author{
Dwi Sutiningsih ${ }^{1,2 *}$, Vilianti Eka Fitri Rahatina ${ }^{1,3}$, Yulianto Prabowo ${ }^{4}$, Aris Haryanto ${ }^{4}$, Mufti \\ Agung Wibowo ${ }^{4}$ \\ ${ }^{1}$ Master of Epidemiology, Postgraduate School, Diponegoro University, Semarang, Indonesia \\ ${ }^{2}$ Faculty of Public Health, Diponegoro University, Semarang, Indonesia \\ ${ }^{3}$ Faculty of Dentistry, Muhammadiyah Semarang University, Semarang, Indonesia \\ ${ }^{4}$ Departement of Health, Central Java Province, Semarang, Indonesia
}

\begin{abstract}
Covid-19 were recorded in Central Java until June 3, 2020. It is estimated to increase every day. However, reports on the epidemiological characteristics of confirmed cases of Covid19 are still limited. The purpose of this study is to describe the confirmed case of COVID-19 in Central Java. This study uses descriptive quantitative design, in which we describe 1,533 cases based on patient characteristics, history of comorbidities, travel history and symptoms. The data of patients processed with descriptive statistical analysis from the Department of Health of Central Java. The results of the study showed that of 1,533 confirmed cases, $64.05 \%$ were male patients and $46.7 \%$ aged $19-44$ years. From 102 death cases, it is dominated by men $(64.7 \%)$ and the elderly $\geq 60$ years $(50 \%)$. The highest IR is the City of Semarang with IR of 17.9 / 100,000 population. The most common history of comorbidities is hypertension and diabetes mellitus with a total of 5 cases each. Cases with a domestic travel history had the highest number of $34.1 \%$ while those without a travel history amounted to $65 \%$. The symptoms experienced by most confirmed patients are Cough, Fever with $10.8 \%$. Thus, it was concluded that confirmed cases in Central Java were spread in 35 cities / regencies with high number. It is necessary to conduct a detailed confirmed case reports to control the policy on Covid-19 prevention and countermeasures in Central Java.
\end{abstract}

Keywords. COVID-19, Confirmed Patient, Central Java, Descriptive

\section{Introduction}

In early 2020 the World Health Organization (WHO) declared a new type of pneumonia called covid-19 as a global pandemic. This disease is known to first spread in Wuhan, Hubei Province, China in early December 2019 [1, 2]. Based on research on viruses it is

\footnotetext{
* Corresponding author: dwi.sutiningsih@live.undip.ac.id
} 
figured that the virus is a type 2 coronavirus or SARS-CoV-2 and was named Covid-19 [2]. This disease affects the respiratory tract and originally transmitted from animals to humans and then between humans. This epidemic spreads very quickly due to human travel across countries that resulted in almost the majority of countries infected [3, 4]. As of July 16,2020 , there are 188 countries with a total infection of $13,554,477$ cases $[5,6]$.

Indonesia ranks 26th out of 188 countries and is number 1 of ASEAN countries facing this pandemic [10]. The Indonesian Ministry of Health stated that up to July 15, 2020, 80,094 people had been confirmed of covid-19, of which 37,247 people were being treated, 39,050 had been declared cured and 3,797 people had died. Based on data up to July 13, 2020, Indonesia also has a quite high CFR (case fatality rate) at $4.76 \%$ and ranks 37 th in the world. Meanwhile, Indonesia occupies the first position as the country with the highest CFR Covid-19 among ASEAN countries [14, 15].

Based on KMK-RI No. HK.01.07/MENKES/413/2020, the confirmed patient is someone who tested positive for Covid-19 virus proven by RT-PCR laboratory examination. Confirmed cases are divided into 2 namely confirmed cases with symptoms (symptomatic) and confirmed cases without symptoms (asymptomatic) while Covid-19 deaths for surveillance purposes are confirmations / probable Covid-19 deaths. The most common symptoms of Covid-19 are fever, fatigue, and dry cough. Some patients may experience aches and pains, nasal congestion, colds, headaches, conjunctivitis, sore throat, diarrhea, loss of smell or skin rashes [25].

The number of confirmed cases of Covid-19 has spread across 34 provinces in Indonesia, Central Java ranked 4th with the total number of confirmed patients of Covid-19 being 5,653 or $7.2 \%$ of the total cases in Indonesia $[11,13]$. As many as 1,533 patients reported from March 3, 2020 to June 3, 2020 where cases were spread in various covid-19 referral hospitals in Central Java. Reports on the epidemiological characteristics of confirmed cases are still limited. The purpose of this study is to describe the characteristics, history of comorbidities and the history of COVID-19 confirmed patients in Central Java. Hopefully that the results of this study will provide information to the public regarding the COVID-19 case in Central Java.

\section{Materials and methods}

This research uses descriptive research design. The data used in the analysis are secondary data from the recording of Covid-19 patients reported to the Department of Health of Central Java. The data analyzed were data from Covid-19 patients from March 3, 2020 to June 3, 2020. The number of recorded data from Covid-19 patients was 1,533. Data analysis was performed using univariate analysis. After the data is displayed in a table or graph, a discussion about the proportion in the frequency distribution will then be conducted. The variables described are Regency, Age, Gender, comorbidities, Travel History, Symptoms and Development of Daily Cases.

\section{Results}

\subsection{Distribution of Confirmed Covid-19 Cases by Gender}

The number of confirmed cases of COVID-19 in Central Java is presented in Graph 1. The graph shows that there are more cases in male patients than in women. Male patients with confirmed status were 982 patients while in female were 551 patients. Similar with the incidence of dead confirmed cases of Covid-19 patients, the number of males were 66 cases while in females were 36 cases. 


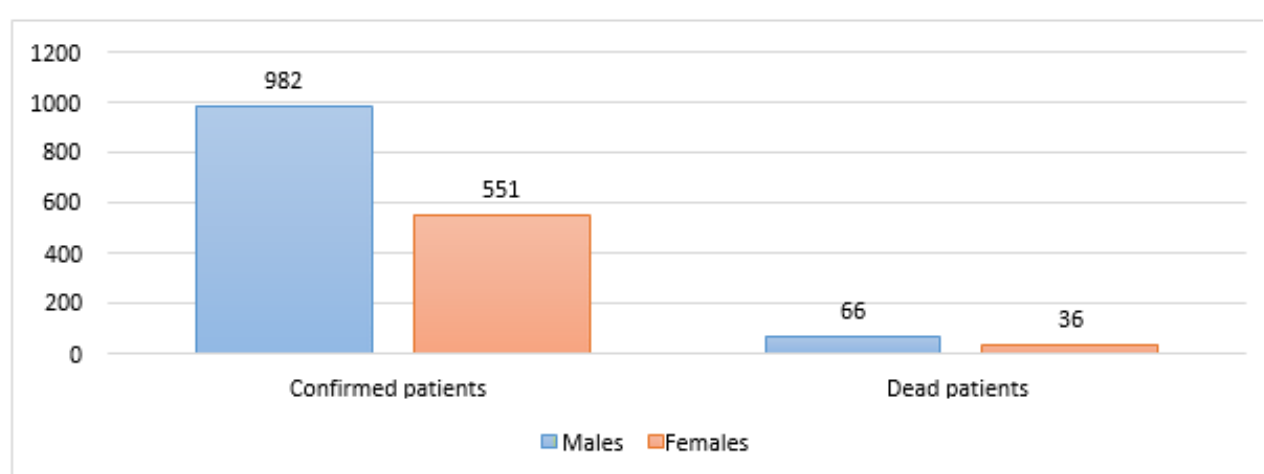

Fig. 1. Distribution of Confirmed Covid-19 Cases and Deaths by Gender

\subsection{Distribution of Confirmed Covid-19 Cases by Age}

Confirmed cases of Covid-19 occurs at all age levels. The distribution of confirmed cases and confirmed dead cases by age is presented in graph 2 below. The graph shows that the most confirmed cases of Covid-19 patients occur in reproductive age, that is the age of 1944 years (adults) with a total of 716 cases while in the confirmed cases the most common deaths occur in the elderly $\geq 60$ years with 51 cases.

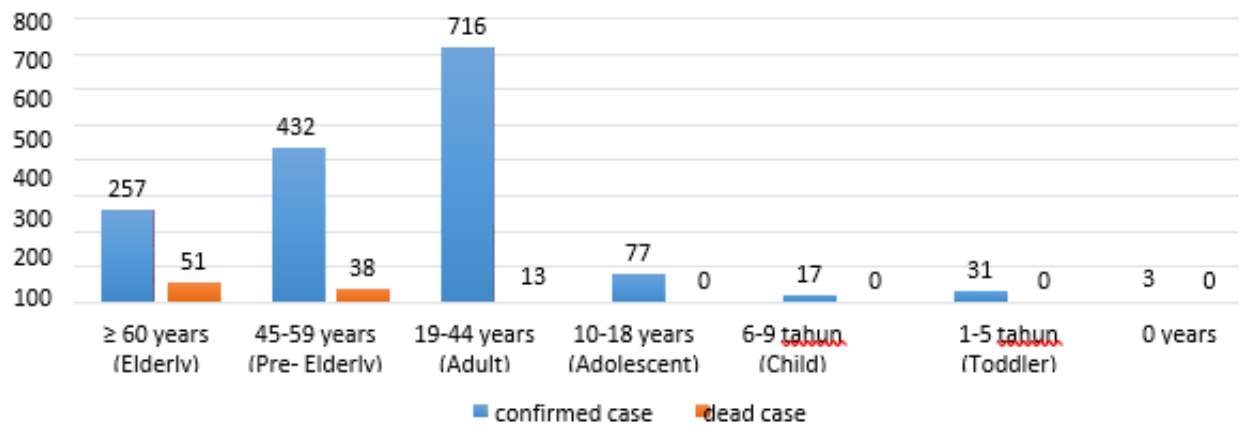

Fig. 2. Distribution of Confirmed Covid-19 Cases and Deaths by Age

According to the graph above, the lowest confirmed cases occur at the age of infants $(0$ years) ie as many as 3 cases and the least number of deaths occur at age $\leq 18$ years with zero case.

\subsection{Distribution of Confirmed Covid-19 Cases by Origin}

Confirmed Covid-19 Cases spread in 35 Cities / Regencies in Central Java Province. The distribution of cases by region is presented in table 1 . It is seen from the table, the highest confirmed cases are in the area of Semarang with 275 cases $(17.9 \%)$. The Incidence Rate (IR) of Salatiga is the highest IR in Central Java with 21.12 / 100,000 population, which means that every 100,000 population there are at least 21 confirmed cases in the Salatiga until April 14, 2020. Furthermore, the other highest IR is occupied by Magelang with 19.65 / 100,000 population. The region with the least number of confirmed cases is Tegal with 3 cases and IR of 1.20 / 100,000 population. However, the lowest IR was in Rembang District with IR of 0.94 / 100,000 population with 6 patients of confirmed cases. 
Table 1. Distribution of Confirmed Cases of covid-19 by Origin (Central Java BPS data for 2019)

\begin{tabular}{|c|c|c|c|c|}
\hline $\begin{array}{l}\text { Regency of } \\
\text { Origin }\end{array}$ & $\begin{array}{l}\text { Number of } \\
\text { cases }\end{array}$ & $\%$ & Population* & IR/100000 \\
\hline Banjarnegara & 49 & 3.2 & 923,192 & 5.31 \\
\hline Banyumas & 60 & 3.9 & $1,693,006$ & 3.54 \\
\hline Batang & 35 & 2.3 & 768,583 & 4.55 \\
\hline Blora & 24 & 1.6 & 865,013 & 2.77 \\
\hline Boyolali & 27 & 1.8 & 984,807 & 2.74 \\
\hline Brebes & 31 & 2 & $1,809,096$ & 1.71 \\
\hline Cilacap & 46 & 3 & $1,727,098$ & 2.66 \\
\hline Demak & 49 & 3.2 & $1,162,805$ & 4.21 \\
\hline Grobogan & 20 & 1.3 & $1,377,788$ & 1.45 \\
\hline Jepara & 25 & 1.6 & $1,257,912$ & 1.99 \\
\hline Karanganyar & 31 & 2 & 886,519 & 3.50 \\
\hline Kebumen & 28 & 1.8 & $1,197,982$ & 2.34 \\
\hline Kendal & 10 & 0.7 & 971,086 & 1.03 \\
\hline Klaten & 26 & 1.7 & $1,174,986$ & 2.21 \\
\hline Kota Magelang & 24 & 1.6 & 122,111 & 19.65 \\
\hline Kota Pekalongan & 12 & 0.8 & 307,097 & 3.91 \\
\hline Kota Salatiga & 41 & 2.7 & 194,084 & 21.12 \\
\hline Kota Semarang & 275 & 17.9 & $1,814,110$ & 15.16 \\
\hline Kota Surakarta & 37 & 2.4 & 519,587 & 7.12 \\
\hline Kota Tegal & 3 & 0.2 & 249,905 & 1.20 \\
\hline Kudus & 37 & 2.4 & 871,311 & 4.25 \\
\hline Magelang & 106 & 6.9 & $1,290,591$ & 8.21 \\
\hline Pati & 23 & 1.5 & $1,259,590$ & 1.83 \\
\hline Pekalongan & 14 & 0.9 & 897,711 & 1.56 \\
\hline Pemalang & 29 & 1.9 & $1,302,813$ & 2.23 \\
\hline Purbalingga & 59 & 3.8 & 933,989 & 6.32 \\
\hline Purworejo & 77 & 5 & 718,316 & 10.72 \\
\hline Rembang & 6 & 0.4 & 638,188 & 0.94 \\
\hline Semarang & 25 & 1.6 & $1,053,786$ & 2.37 \\
\hline Sragen & 32 & 2.1 & 890,518 & 3.59 \\
\hline Sukoharjo & 43 & 2.8 & 891,912 & 4.82 \\
\hline Tegal & 18 & 1.2 & $1,440,698$ & 1.25 \\
\hline Temanggung & 55 & 3.6 & 772,018 & 7.12 \\
\hline Wonogiri & 11 & 0.7 & 959,492 & 1.15 \\
\hline Wonosobo & 78 & 5.1 & 790,504 & 9.87 \\
\hline Jawa Tengah & 67 & 4.4 & - & - \\
\hline Total & 1533 & 100 & - & - \\
\hline
\end{tabular}




\subsection{Distribution of comorbidities in Confirmed Covid-19 patients}

The table below shows the distribution of comorbidities in confirmed and deceased patients with Covid-19 in Central Java up to 14 April 2020. Confirmed patients that had history of comorbidities mostly hypertension and diabetes mellitus with the same amount that is 5 cases $(1.1 \%)$. Even so, in dead patients mostly are characterized with diabetes mellitus that are 3 patients $(2.9 \%)$.

Table 2. distribution of covid-19 patients with comorbidities in Central Java ( $\mathrm{n}=1533)$

\begin{tabular}{lllll}
\hline Comorbidities & \multicolumn{2}{c}{ Infected } & Dead & \\
& $\mathbf{f}$ & $\mathbf{\%}$ & $\mathbf{f}$ & $\mathbf{\%}$ \\
\hline Asthma & 1 & 0.2 & 0 & 0.0 \\
Diabetes mellitus & $\mathbf{5}$ & $\mathbf{1 . 1}$ & $\mathbf{3}$ & $\mathbf{2 . 9}$ \\
Diabetes mellitus, hypertension & 1 & 0.2 & 0 & 0.0 \\
Diabetes Mellitus, Others & 1 & 0.2 & 0 & 0.0 \\
Diabetes Mellitus, COPD & 0 & 0.0 & 0 & 0.0 \\
Heart failure & 1 & 0.2 & 2 & 2.0 \\
Chronic Kidney & 1 & 0.2 & 0 & 0.0 \\
Chronic Kidney, Hypertension & 0 & 0 & 1 & 1.0 \\
Hypertension & $\mathbf{5}$ & $\mathbf{1 . 1}$ & 2 & 2.0 \\
Hypertension, Diabetes Mellitus & 0 & 0.0 & 1 & 1.0 \\
Hypertension, Diabetes Mellitus,, & 0 & 0.0 & 1 & 1.0 \\
Chronic Kidney & & & & \\
Hypertension, stroke & 0 & 0.0 & 0 & 0.0 \\
Coronary heart & 0 & 0.0 & 1 & 1.0 \\
COPD & 0 & 0.0 & 1 & 1.0 \\
Rheumatoi & 0 & 0.0 & 0 & 0.0 \\
d Arthritis & 2 & 0.4 & 0 & 0,0 \\
Others & 433 & 96.2 & 90 & 88.2 \\
No history / & $\mathbf{4 5 0}$ & $\mathbf{1 0 0 , 0}$ & $\mathbf{1 0 2}$ & $\mathbf{1 0 0 , 0}$ \\
no record & & & &
\end{tabular}

\subsection{Distribution of Confirmed Cases Based on Travel History}

The table below shows that from 997 or $65 \%$ of cases, there were no travel history recorded. Of the patients who had a travel history, the majority had a domestic travel history, which were 522 cases (34.1\%). 
Table 3. Distribution of Confirmed Cases Based on Travel History

\begin{tabular}{lcc}
\hline \multicolumn{1}{c}{ Travel History } & Frequency & $\mathbf{\%}$ \\
\hline Domestic Travel history & 522 & 34.1 \\
Overseas Travel history & 14 & 0.9 \\
$\begin{array}{l}\text { Domestic and Overseas Travel } \\
\text { history }\end{array}$ & 0 & 0 \\
No travel history/ Not recorded & 997 & 65.0 \\
\hline Total & $\mathbf{1 5 3 3}$ & $\mathbf{1 0 0}$ \\
\hline
\end{tabular}

\subsection{Distribution of Symptoms in Confirmed Patients}

The table below shows that half of the total cases have no symptoms or are not recorded (54.9\%). In patients who arrived with symptoms, it is known that mostly had the symptoms of cough and fever were 165 cases (10.8\%) and with only fever symptoms as much as 146 $(9.5 \%)$. Even so, the symptoms experienced by patients with positive Covid-19 are quite varied but the majority experience cough and fever.

Table 4. Distribution of Symptoms in Confirmed Covid-19 Patients

\begin{tabular}{|c|c|c|}
\hline Symptoms experienced & Frequency & $\%$ \\
\hline Cough & 124 & 8,1 \\
\hline Cough, fever & 165 & 10,8 \\
\hline Cough, Fever, diarrhea & 1 & 0,1 \\
\hline Cough, Fever, Diarrhea & 3 & 0,2 \\
\hline Cough, Fever, Diarrhea, Shivering & 1 & 0,1 \\
\hline $\begin{array}{l}\text { Cough, Fever, Diarrhea, Nausea, } \\
\text { Headache, asphyxiate }\end{array}$ & 1 & 0,1 \\
\hline Cough, Fever, Diarrhea, Colds & 1 & 0,1 \\
\hline Cough, Fever, Diarrhea, Colds, Nausea & 1 & 0,1 \\
\hline Cough, Fever, Diarrhea, asphyxiate & 1 & 0,1 \\
\hline Cough, Fever, Fatigue & 2 & 0,1 \\
\hline Cough, Fever, Fatigue, Nausea & 1 & 0,1 \\
\hline $\begin{array}{l}\text { Cough, Fever, Fatigue, Nausea, } \\
\text { Headache }\end{array}$ & 1 & 0,1 \\
\hline Cough, Fever, Fatigue, Colds & 3 & 0,2 \\
\hline Cough, Fever, Shivering & 1 & 0,1 \\
\hline Cough, Fever, Shivering, Nausea & 1 & 0,1 \\
\hline Cough, Fever, Shivering, Colds & 1 & 0,1 \\
\hline Cough, Fever, Shivering, asphyxiate & 1 & 0,1 \\
\hline Cough, Fever, Nausea & 6 & 0,4 \\
\hline Cough, Fever, Nausea, Colds & 1 & 0,1 \\
\hline $\begin{array}{l}\text { Cough, Fever, Nausea, Stomach Pain, } \\
\text { asphyxiate }\end{array}$ & 1 & 0,1 \\
\hline Cough, Fever, Nausea, asphyxiate & 1 & 0,1 \\
\hline Cough, Fever, Colds & 40 & 2,6 \\
\hline Cough, Fever, Colds, Nausea & 3 & 0,2 \\
\hline $\begin{array}{l}\text { Cough, Fever, Colds, Headaches, Sore } \\
\text { Throat }\end{array}$ & 1 & 0,1 \\
\hline Cough, Fever, Colds, Sore Throat & 1 & 0,1 \\
\hline Cough, Fever, Colds, asphyxiate & 2 & 0,1 \\
\hline
\end{tabular}


0,1

Cough, Fever, Headache, Sore Throat

Cough, Fever, Headache, Sore Throat,

asphyxiate

Cough, Fever, Stomach Pain

Cough, Fever, Sore Throat, asphyxiate

Cough, Fever, asphyxiate

Cough, diarrhea

Cough, Diarrhea, Fatigue

Cough, Diarrhea, Fatigue, asphyxiate

Cough, Diarrhea, Nausea

Cough, Fatigue

Cough, fatigue, nausea

Cough, nausea

Cough, Nausea, Fatigue

Cough, Nausea, Fatigue, asphyxiate

Cough, Nausea, Colds

Cough, Nausea, Sore Throat

Cough, Nausea, asphyxiate

Cough and cold

Cough, Colds, Fever

Cough, Cold, Sore Throat

Cough, Headache

Cough, Headache, Stomach Pain

Cough, Headache, Sore Throat

Cough, Stomach Pain, asphyxiate

Cough, sore throat

Cough, sore throat, asphyxiate

Cough, asphyxiate

Cough, Fever, Headache

Fever

Fever, Cough, Colds

Fever, Diarrhea

Fever, Fatigue

Fever, Fatigue, Nausea

Fever, Fatigue, asphyxiate

Fever, Shivering

Fever, Nausea

Fever, colds

Fever, Headache

Fever, Sore Throat

Fever, Sore Throat, asphyxiate

Fever, asphyxiate

Diarrhea

Diarrhea, asphyxiate

Fatigue

Fatigue, Shivering

Fatigue, Nausea, Stomach Pain

Fatigue, headache

Shivering

Nausea

Nausea, Headache, Sore Throat
0,1

1,0

0,1

0,1

0,1

0,1

0,1

0,1

0,4

0,1

0,1

0,1

0,1

0,1

1,4

0,1

0,1

0,1

0,1

0,1

0,1

0,3

0,1

0,5

0,1

9,5

0,1

0,1

0,1

0,1

0,1

0,1

0,3

0,1

0,1

0,1

0,1

0,1

0,4

0,1

0,4

0,1

0,1

0,1

0,1

0,4

0,1 


\begin{tabular}{lcc} 
Nausea, asphyxiate & 1 & 0,1 \\
Cold & 4 & 0,3 \\
Headache & 2 & 0,1 \\
Headache, stomach ache & 1 & 0,1 \\
Headache, sore throat & 2 & 0,1 \\
Stomach ache, sore throat & 1 & 0,1 \\
Sore throat & 4 & 0,3 \\
Hard to breathe & 8 & 0,5 \\
asphyxiate, Colds, Coughs & 1 & 0,1 \\
Etc & 30 & 2,0 \\
There are no symptoms & 31 & \\
Unclear / not recorded & 810 & \\
\hline Total & 1533 & 100,0 \\
\hline
\end{tabular}

\section{Discussion}

Central Java Province had recorded that from 3 March 2020 to 3 June 2020, there were 1,533 positive confirmed cases of Covid-19. In the cases based on gender, the number of males were 982 cases or $60.79 \%$ while females were 551 cases or $39.21 \%$. Similarly, in the dead case the number of males were 66 cases compared to 36 cases of females. This is the same as the results of research conducted in China, where in 44,672 confirmed cases, $51.4 \%$ of were males and $48.6 \%$ of female. Whereas in the dead case $63.8 \%$ of cases occurred in males and $36.2 \%$ of cases in females [17]. However, the results differ from studies conducted in Zhejiang in which $59.34 \%$ of cases were females and $40.66 \%$ were males [18]. Based on the data above, it is figured that the most confirmed cases occurred in patients aged 19-40 years (adults) as much as $46.7 \%$ and $50 \%$ of cases died. The similar thing happened in the results of research in Beijing with the highest number of confirmed cases was $42,7 \%$ at the age of 13-44 years [19].

There are 35 regencies / cities in Central Java with Semarang City as the Capital. As the provincial capital, Semarang has the highest case incidence of 275 cases or $17.6 \%$ of the total cases. This is due to the fact that the high mobility in the city is also influenced by the number of referral hospitals in Semarang. According to WHO, it is important to know the average influx of patients each day to determine the size of the waiting room and avoid the possibility of excessive patient. As long as the number of daily patients are increased it can increase the risk of nosocomial infection [16]. The number of factory or clustered activities in Semarang is also very high, based on data of Regional Development Agency of Semarang, there are at least 3 industrial areas in Semarang and in the city center there are various government offices which also cause crowds [20]. Tegal has the lowest confirmed cases in Central Java, which is 3 cases or $0.2 \%$ of the total cases. Meanwhile, the strict supervision, examinations, closed- contact tracking, treatment and isolation are the main targets in the prevention of covid-19 infections [3].

The distribution of comorbidities in confirmed Covid-19 cases in Central Java up to April 14, 2020 shows that the confirmed patients mostly had hypertension and diabetes mellitus as comorbidities with the same number of 5 cases each (1.1\%). Even so, in dead patients, mostly accompanied by diabetes mellitus that were 3 patients $(2.9 \%)$. This is similar to studies conducted in China, hypertension (OR: 2.29, $\mathrm{P}<0.001$ ), diabetes mellitus (OR: 2.47, $\mathrm{P}<0.001$ ), chronic obstructive pulmonary disease (COPD) (OR: 5.97, P $<0.001$ ), heart disease (OR: 2.93, $\mathrm{P}<0.001$ ), and cerebrovascular disease (OR: $3.89, \mathrm{P}=$ 0.002) (21). Researchers in New York also showed the same case where the most comorbid diseases in covid-19 were hypertension $(3026 ; 56.6 \%)$, obesity $(1737 ; 41.7 \%)$ and diabetes mellitus $(1808 ; 33.8 \%)$ [22]. In the dead case in China, hypertension was the most common 
disease (58 [30\%] patients), followed by diabetes mellitus (36 [19\%] patients) and coronary heart disease (15 [8\%] patients) [23].

No symptoms or not recorded were symptoms with the highest number experienced by confirmed covid-19 patients with more than half of the total cases $(54.9 \%)$. In cases that arrived with symptoms, it is known that most have the symptoms of cough and fever as many as 165 cases (10.8\%) and who only had fever symptoms were $146(9.5 \%)$. Even so, the symptoms experienced by patients with positive Covid-19 were quite varied but the majority experienced coughing and fever. Other studies suggest that the highest symptoms seen in confirmed cases were fever $(91.3 \%, 95 \%$ CI: $86-97 \%)$, followed by cough (67.7\%, 95\% CI: 59-76\%), fatigue (51.0\%, $95 \%$ CI: 34-68\%) and dyspnea $(30.4 \%, 95 \%$ CI: $21-40 \%$ ) [24]. Common signs and symptoms of COVID-19 infection include symptoms of acute respiratory disorders such as fever, coughing and asphyxiate. The average incubation period is 5-6 days with the longest incubation period to 14 days. In severe cases of COVID-19, it can cause pneumonia, acute respiratory syndrome, kidney failure, and even death [25].

Coronavirus is a zoonosis (transmitted between animals and humans). Research says that SARS is transmitted from civet cats to humans and MERS from camels to humans. Meanwhile, the animal that is the source of COVID-19 transmission is still unknown. The average incubation period for COVID-19 is 5-6 days, with a range between 1 and 14 days but can reach 14 days. The highest risk of transmission is obtained in the first days of the disease due to high concentration of the virus in the secretions. An infected person can directly transmit it up to 48 hours before the symptom onset (presymptomatic) and up to 14 days after the symptom onset [25]. The results of research in Central Java showed that 997 or $65 \%$ of cases were not recorded or had no travel history. Of the patients who had a travel history, the majority had a domestic travel history, which were 522 cases $(34.1 \%)$. The governor of Central Java in the guidelines for acceleration of community-based covid-19 handling through the formation of the 'jogo tonggo' task force said that the people are dealing directly with the transmission of Covid-19 and therefore, the prevention of Covid19 transmission must put the community at the forefront against Covid-19 with full support from the government, universities, companies, banking institutions, financial institutions, professional organizations, mass media, social media, non-governmental organizations, sectoral organizations, mass organizations and other stakeholders. Resistance to the spread and transmission of Covid-19 must be carried out in a systematic, structured, comprehensive, continuous and long-term manner, so that effective, neat and strong organization is needed [9].

\section{Conclusion}

Confirmed Covid-19 cases in Central Java were recorded 1,533 cases with 102 deaths up to 14 April 2020. In this case the most infected were people aged 19-44 years and most died are patients aged above 60 years or the elderly. Confirmed cases are also more common in male patients than in females, as well as the cases of death. The death and infection of a person are also affected by general health because the highest comorbidity factors such as hypertension and diabetes mellitus found in many confirmed and dead cases. The city of Semarang has a high IR due to geographical conditions and its functions as the provincial capital, so the government has set an acceleration program for handling Covid-19 in Semarang. The most transit area is there are no travel history so this adds to the belief that many infections occur in only one area or local. Specific actions or policies regarding contact with confirmed patients are needed, because the easiest transmission is through droplets. It is necessary to conduct a complete and clear documentation of data so that the policies and rules set are appropriate and can be the basis of the policy. This research is also 
expected to provide input and valid data regarding the distribution of confirmed cases in Covid-19 in Central Java, considering this case increase day by day.

We would like to convey our gratitude to the Department of Health of Central Java that has been giving permission and cooperation in carrying out the study so that it can run smoothly. We would also like to convey our gratitude to Masters of Epidemiology, Graduate school of Diponegoro University in Semarang that gives the permission and support in conducting this research.

\section{References}

1. WHO, WHO Statement Regarding Cluster of Pneumonia Cases in Wuhan China [Internet], World Health Organization, (2020) [cited 2020 Mar 19], Available from: https:/www,who,int/china/news/detail/09-01-2020-who- statement-regarding-clusterof-pneumonia-cases-in-wuhan-china.

2. WHO, Naming the coronavirus disease (COVID-19) and the virus that causes it, Coornavirus disease 2019, (2020).

3. WHO, Statement on the second meeting of the International Health Regulations (2005) Emergency Committee regarding the outbreak of novel coronavirus (2019nCoV) [Internet], World Health Organization, (2020) [cited 2020 Apr 26], Available from: https://www, who,int/news-room/detail/30-01-2020-statement-on-the-secondmeeting-of- the-international-health-regulations-(2005)-emergency-committeeregarding-the-outbreak-of-novel-coronavirus- (2019-ncov).

4. WHO, WHO Director-General's opening remarks at the media briefing on COVID19, Geneva; (2020).

5. WHO, Coronavirus Disease 2019 Situation Report - 163, Vol, 14, Coronavirus disease 2019, Geneva; (2020).

6. Johns Hopkins University (JHU), COVID-19 Dashboard by the Center for Systems Science and Engineering (CSSE) at Johns Hopkins University (JHU), New York; (2020).

7. Tingkat kematian COVID-19 di RI kini di atas AS [Internet], Semarang; (2020), Available from: https://news, detik,com/berita/d-5092727/tingkat-kematian-covid-19di-ri-kini-di-atas-as/2.

8. Situasi terkini perkembangan coronavirus diseases [Internet], Semarang; (2020), Available from: https://covid19,kemkes,go,id/situasi-infeksi-emerging/info-coronavirus/situasi-terkini-perkembangan-coronavirus2020/\#,Xw_tyygzbIU.

9. Gubernur Jawa Tengah, Instruksi Gubernur Jawa Tengah selaku ketua gugus tugas percepatan penanganan covid - 19 di provinsi jawa tengah nomor 1 tahun 2020 Tentang pemberdayaan masyarakat dalam percepatan penanganan covid-19 di tingkat rukun warga (rw) melalui pembentukan "satgas jogo tonggo", Semarang : Kantor Gubernur Jawa Tengah; (2020).

10. BNPB, Peta Sebaran, Jakarta; (2020).

11. Kemenkes, Pedoman Pencegahan dan Pengendalian Coronavirus Disease (Covid-19), Jakarta: Kementerian Kesehatan RI; (2020), 1-116 p.

12. Gugus Tugas Percepatan Penanganan Covid, Peta Sebaran [Internet], Semarang; (2020), Available from : https://covid19,go,id/peta-sebaran.

13. Dinkes Provinsi Jateng, Data Kasus Pasien Pasien Covid-19 di Provinsi Jawa Tengah, Semarang; (2020).

14. Kemenkes RI, Pedoman Pencegahan dan Pengendalian Coronavirus Disease (COVID19), Germas, Jakarta: Keme; (2020), 0-115 p.

15. Kemenkes RI, Situasi Infeksi Emerging [Internet], Jakarta; 
(2020), Available from :https://covid19,kemkes,go,id/category/situasiinfeksi-emerging/info-corona-virus/\#,Xw_qcigzbIU

16. WHO, Pusat Pengobatan Infeksi Saluran Pernapasan Akut Berat, Geneva; (2020).

17. The Novel Coronavirus Pneumonia Emergency Response Epidemiology Team, The Epidemiologica Characteristics of an Outbreak of 2019 Novel Coronavirus Diseases (COVID-19) - China, 2020, China CDC Weekly, (2020).

18. G,-Q, Qian, N,-B, Yang, F, Ding, A,H,Y, Ma, Z,-Y, Wang, Y,-F, Shen, C,-W, Shi, X, Lian, J,-G, Chu, L, Chen, Z,- Y, Wang, D,-W, Ren, G,-X, Li, X,-Q, Chen, H,-J, Shen, and $\mathrm{X},-\mathrm{M}$, Chen, Epidemiologic and clinical characteristics of 91 hospitalized patients with COVID-19 in Zhejiang, China: a retrospective, multi-centre case series, Oxford University Press; (2020), Available from : doi: 10,1093/qjmed/hcaa089.

19. Sijia Tiana, Nan Hub, Jing Loua, Kun Chenc, Xuqin Kanga , Zhenjun Xiang, Hui Chenb, Dali Wang, Ning Liue, Dong Liuf, Gang Cheng, Yongliang Zhang, Dou Li, Jianren Li, Huixin Liana, Shengmei Niua, Luxi Zhanga, Jinjun Zhanga, Characteristics of COVID-19 infection in Beijing, Elsevier; 2020, Available from : https://doi,org/10,1016/j,jinf,2020,02,018 0163-4453/C (2020).

20. Bappeda Kota Semarang, Publikasi Bappeda Kota Semarang [Internet], Semarang; (2020), Available from https://bappeda,semarangkota,go,id/uploaded/publikasi/BAB_II.pdf.

21. Bolin Wang, Ruobao Li, Zhong Lu, Yan Huang, Does comorbidity increase the risk of patients with COVID-19: evidence from meta-analysis, NCBI; (2020), Available from : doi: 10,18632/aging, 103000 .

22. Safiya Richardson, MD, MPH, Jamie S, Hirsch, MD, MA, MSB, Mangala Narasimhan, et al, Presenting Characteristics, Comorbidities, and Outcomes Among 5700 Patients Hospitalized With COVID-19 in the New York City Area, JAMA; (2020), Available from : doi:10,1001/jama,2020,6775.

23. Fei Zhou,Ting Yu,Ronghui Du,Guohui Fan,Ying Liu,Zhibo Liu,Jie Xiang, Yeming Wang,Bin Song,Xiaoying Gu,Lulu Guan,Yuan Wei,Hui Li,Xudong Wu,Jiuyang $\mathrm{Xu}$,Shengjin Tu,Yi Zhang,Hua Chen,Bin Cao, Clinical course and risk factors for mortality of adult inpatients with COVID-19 in Wuhan, China: a retrospective cohort study, TheLancet; (2020), Available from : https://doi,org/10,1016/ S01406736(20)30566-3.

24. JingYang, YaZheng, XiGou, KePu, ZhaofengChen, QinghongGuo, RuiJi, HaojiaWang, YupingWang, YongningZhou, Prevalence of comorbidities and its effects in patients infected with SARS-CoV-2: a systematic review and meta-analysis, Elsevier; (2020), Available from : https://doi,org/10,1016/j,ijid,2020,03,017.

25. Kementerian Kesehatan RI, KEPUTUSAN MENTERI KESEHATAN REPUBLIK INDONESIA NOMOR HK,01,07/MENKES/413/2020 TENTANG PEDOMAN PENCEGAHAN DAN PENGENDALIAN CORONAVIRUS DISEASE 2019 (COVID-19), Jakarta; (2020). 